
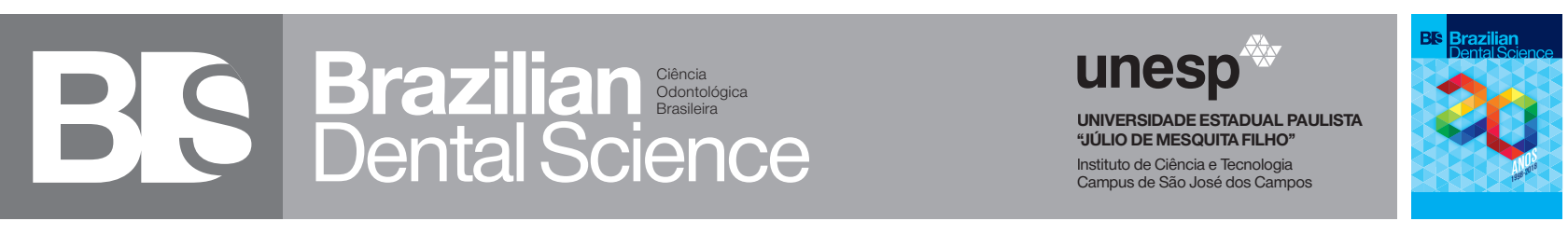

\title{
Effect of shear bond strength of metallic orthodontic brackets bonded with and without dental adhesive
}

\author{
Efeito da resistência ao cisalhamento de braquetes ortodônticos unidos com e sem adesivo dentário \\ Jaiane Bandoli MONTEIRO${ }^{1}$, Ricardo Toledo ABREU², Lívia SALGADO ${ }^{3}$, Thaís Cachuté PARADELLA ${ }^{4}$, Ivone de Oliveira SALGADO ${ }^{3}$, \\ Renato CILLI ${ }^{3}$ \\ 1 - São Paulo State University (Unesp) - Institute of Science and Technology, São José dos Campos - Department of Dental Materials and \\ Prosthodontics - SP - Brazil. \\ 2 - São Paulo State University (Unesp) - Institute of Science and Technology, São José dos Campos - Department of Restorative Dentistry \\ - SP - Brazil. \\ 3 - Department of Restorative Dentistry - Juiz de Fora Federal University - School of Dentistry (UFJF) - Juiz de Fora - MG - Brazil. \\ 4 - São Paulo State University (Unesp) - Institute of Science and Technology, São José dos Campos - Department of Biosciences and Oral \\ Diagnosis - SP - Brazil.
}

\section{ABSTRACT}

Objective: The aim of this study was to evaluate the shear bond strength (SBS) of two materials for bonding orthodontic brackets on dental enamel before and after thermocycling. Material and Methods: Forty bovine incisors were divided into four groups $(\mathrm{n}=10)$. All teeth were etched with 35\% phosphoric acid (3M Espe). For bonding of the brackets, G1 and G2 received orthodontic composite resin (Fill Magic Ortodôntico) and G3 and G4, an adhesive (ScotchBond) was used before the orthodontic resin Transbond XT (3M Unitek). G1 and G3 were kept at $37^{\circ} \mathrm{C}$ for $24 \mathrm{~h}$ and $\mathrm{G} 2$ and G4 were submitted to thermocycling $\left(5000\right.$ cycles, at $5^{\circ} \mathrm{C}-55^{\circ} \mathrm{C}$ ) prior to SBS testing, performed by a universal machine (EMIC) at $1 \mathrm{~mm} / \mathrm{min}$, with a 50kgf load cell. Results were analyzed with two-way ANOVA, followed by Tukey's test $(\mathrm{p}=0.05)$. Adhesive surfaces were evaluated through stereomicroscopy and classified according to the type of failure presented. Results: Surface treatment with dental adhesive presented higher SBS values, regardless thermocycling (G3: 12.01 MPa; G4: 12.36 $\mathrm{MPa}$ ) and the lowest values occurred in G2 (8.89 MPa). For groups without adhesive and with thermocycling, a higher number of completely adhesive failures between composite and enamel were present. For groups in which dental adhesive was used, regardless thermocycling, the failures were mainly adhesive between composite and the bracket. Conclusion: Surface etching of enamel with $35 \%$ phosphoric acid with or without adhesive showed a positive effect on SBS. The application of adhesive on enamel surface contributed to the maintenance of SBS values after thermocycling.

\section{KEYWORDS}

Aging; Orthodontic brackets; Composite resins; Shear strength.

\section{RESUIMO}

Objetivo: O objetivo desse estudo foi avaliar a resistência ao cisalhamento de dois materiais para fixação de braquetes ortodônticos ao esmalte dentário antes e após a termociclagem. Material e Métodos: Quarenta incisivos bovinos foram divididos em quatro grupos $(n=10)$. Todos os dentes foram condicionados com ácido fosfórico a 35\% (3M Espe). Para a fixação dos braquetes, G1 e G2 receberam a resina composta ortodôntica (Fill Magic Ortodôntico) e G3 e G4, um adesivo dentário (ScotchBond) foi usado antes da resina ortodôntica Transbond XT (3M Unitek). G1 e G3 foram mantidos a $37^{\circ} \mathrm{C}$ por $24 \mathrm{~h}$ e G2 e G4 foram submetidos à ciclagem térmica (5000 ciclos, de $5^{\circ} \mathrm{C}-5^{\circ} \mathrm{C}$ ) anterior ao teste de resistência ao cisalhamento, realizado por máquina universal (EMIC) a 1 $\mathrm{mm} / \mathrm{min}$, com célula de carga de $50 \mathrm{kgf}$. Os resultados foram analisados com ANOVA 2-fatores, seguida do teste de Tukey $(p=0,05)$. As superfícies adesivas foram avaliadas através de estereomicroscopia e classificadas de acordo com o tipo de falha presente. Resultados: O tratamento de superfície com adesivo dentário apresentou maiores valores de resistência ao cisalhamento, independente da termociclagem (G3: 12,01 MPa; G4: 12,36 MPa) e os menores valores ocorreram para G2 (8,89 MPa). Para os grupos sem adesivo e com termociclagem, o maior número de falhas predominantemente adesivas entre resina composta e esmalte estava presente. Para os grupos em que o adesivo dentário foi utilizado, independente da termociclagem, as falhas foram principalmente adesivas entre resina composta e o braquete. Conclusão: $\mathrm{O}$ condicionamento superficial do esmalte com ácido fosfórico a $35 \%$ com ou sem adesivo mostrou um efeito positivo sobre a resistência ao cisalhamento. A aplicação de adesivo na superfície do esmalte contribuiu para a manutenção dos valores de resistência ao cisalhamento após a termociclagem.

\section{PALAVRAS-CHAVE}

Envelhecimento; Braquete ortodôntico; Resinas compostas; Força de cisalhamento. 


\section{INTRODUCTION}

$\mathrm{T}$ he concept of adhesion of dental materials to enamel was first introduced in 1955 by Michael G. Buonocore [1] and only in 1979 there was a description of bonding orthodontic brackets to enamel with photocured composite resins [2]. The development of bonding materials and orthodontic brackets has contributed to simplifying the process of bonding, with the reduction of operatory steps, and consequently, reducing time [3-5].

The adequate bonding of orthodontic brackets to teeth structure is a prerequisite for a successful orthodontic treatment. However, to achieve adequate bonding without damaging tooth structure can be challenging $[4,6]$, thus, the bonding system used to bond orthodontic brackets to teeth structure must not fail during the period of orthodontic treatment [4]. One of the methods of enamel treatment is the etching of the surface with phosphoric acid, which can be combined with different adhesive systems and composite resins [7]. An acceptable bonding system must resist to the forces applied by orthodontic wires, such as shear, in an oral environment where restorations are aged $[8,9]$.

Shear bond strength (SBS) testing is directly linked to the evolution of bonding materials, since it is the most efficient and used method to quantify the bonding resistance of orthodontic brackets to human enamel [10]. The influence of each variable involved (surface treatment, adhesive systems and aging) must contribute to the achievement of an ideal bonding, with the primordial intention of obtaining clinical success.

The purpose of the present study was to evaluate the (SBS) of metallic orthodontic brackets to bovine enamel using different adhesive systems and composite resins before and after thermocycling. The null hypothesis was that neither surface treatments nor in vitro aging would affect SBS.

\section{MATERIAL AND METHODS}

\section{Teeth preparation}

For the confection of the specimens, recently extracted bovine teeth were used. Teeth were obtained in a certified slaughterhouse. Criteria for inclusion of teeth included absence of abnormalities on the surface of enamel, absence of fractures or surface cracks. All teeth were analyzed under stereomicroscopy (Discovery V20, Zeiss, Göttingen, Germany) and a total of 40 teeth were chosen. Crowns were separated from roots at the enamel-cement joint, using a circular saw (Edenta, Labordental, SP, Brazil) under constant water cooling. Cleaning of the enamel surface was performed using rubber cups, pumice and water for $20 \mathrm{~s}$, for the removal of surface debris. All teeth were dried for $20 \mathrm{~s}$ and posteriorly, sterilized in autoclave (Cristófoli Equipments of Biosecurity Ltda, Campo Mourão, Paraná, Brazil) with $134^{\circ} \mathrm{C}$ for $15 \mathrm{~min}$.

\section{Sample preparation}

To standardize the enamel parallel surface, the lingual surface was embedded in acrylic resin (Jet, Clássico, SP, Brazil) at the center of a PVC tube (Polyvinyl chloride, Tigre, Joinville, Brazil), leaving the buccal surface exposed. Using a glass plate, the enamel surface was correctly positioned and held down until final setting of the acrylic. All enamel buccal surfaces were polished with \#600 and \#1200 silicon carbide sandpaper (Norton Abrasives, Guarulhos, SP, Brazil) using a politrix (EcoMet 250 Grinder Polisher, Buehler, Lake Buff, Illinois, USA), under water cooling. Before the bonding of the orthodontic brackets, all surfaces were cleaned with isopropyl alcohol to remove any debris from the polishing of the surfaces.

\section{Experimental groups and bonding procedure}

The division of the groups, as well as the materials used in this study and their composition are described in Table I. 
Table I - Experimental groups and materials used.

\begin{tabular}{|c|c|c|c|c|}
\hline Group & Enamel etching & $\begin{array}{l}\text { Adhesive system and } \\
\text { cementation agent }\end{array}$ & Composition & Thermocycling \\
\hline G1 & \multirow{4}{*}{$\begin{array}{c}\text { 35\% phosphoric acid } \\
\text { (Scotchbond Etchant, 3M } \\
\text { Espe Dental Products, St } \\
\text { Paul, Mn, USA) }\end{array}$} & & \multirow[b]{2}{*}{$\begin{array}{l}\text { bisphenylglycidyl dimethacrylate (BisG- } \\
\text { MA), ethoxylated bisphenol-A dimetha- } \\
\text { crylate (Bis-EMA), UDMA, triethylene } \\
\text { glycol dimethacrylate (TEGMA), ethyl } \\
\text { 4-dimethylaminobenzoate (EDAB), BHT, } \\
\text { photoiniciator, resin load, ytterbium fluori- } \\
\text { de and pigments }\end{array}$} & \multirow[t]{2}{*}{ Without } \\
\hline G2 & & $\begin{array}{c}\text { Fill Magic Ortodôntico } \\
\text { (Vigodent/Coltene, RJ, } \\
\text { Brazil) }\end{array}$ & & \\
\hline G3 & & Adhesive: Adper Scot- & Primer:triethyleneglycoldimethacrylate(TEGD- & Without \\
\hline G4 & & $\begin{array}{l}\text { chbond (3M Espe Dental } \\
\text { Products, St. Paul, MN, } \\
\text { USA) + Transbond }{ }^{\mathrm{TM}} \text { XT } \\
\text { (3M Unitek, Mn, CA, USA) }\end{array}$ & $\begin{array}{l}\text { MA),bisphenylglycidyldimethacrylate(BisGMA) } \\
\text { Adhesivepaste:silica,Bis-GMA, silane,N-dimethyl- } \\
\text { benzocaine, hexa-fluoride-phosphate }\end{array}$ & With \\
\hline
\end{tabular}

All enamel surfaces were etched using 35\% phosphoric acid (ScotchbondTM Etchant, 3M Espe, St. Paul, MN, USA) for 30 s, following by rinsing and complete air drying using triple syringe, free of oil. Specimens were randomly divided into two groups $(n=20)$ according to the adhesive system and composite resin used: half of the specimens received orthodontic resin (Fill Magic Ortodôntico, Vigodent/Coltene) and the other half received the application of dental adhesive (Adper Scothbond, 3M Espe, St. Paul, MN, USA) and orthodontic resin (Transbond ${ }^{\mathrm{TM}}$ XT, 3M Unitek, Monrovia, CA, USA). According to the manufacturer, the orthodontic resin Fill Magic does not require dental adhesive. A single type of NiCr metallic bracket was chosen (Orthodontic Bracket M.B.T. Prescription Standard, Dental Morelli Ltda, Sorocaba, SP, Brazil; $9.75 \mathrm{~mm}^{2}$ base area; $-6^{\circ}$ torque and $0^{\circ}$ angulation; lot: 1663210). All procedures were performed by a single operator.

In groups $\mathrm{G} 3$ and $\mathrm{G} 4$, a thin layer of dental adhesive (ScotchBond, 3M Espe, St. Paul, MN, USA) was actively applied using a microbrush (Vigodent, Rio de Janeiro, RJ, Brazil) on the dry enamel surface for $20 \mathrm{~s}$ and photocured for $40 \mathrm{~s}$ with light emitting diode (LED) (high intensity of $1000 \mathrm{~mW} / \mathrm{cm}^{2}$; wavelength ranging from 440 to $480 \mathrm{~nm}$ - Radii-Cal, SDI, Dublin, Ireland).

Brackets were kept stable using orthodontic tweezers (serial number: 75.01.022; Morelli Ortodontia, Sorocaba, SP, Brazil) to receive a single increment of composite resin. Then, they were positioned on the enamel surface, held down using a $750 \mathrm{~g}$ load for $10 \mathrm{~s}$, to ensure that the base of the bracket was parallel bonded to the enamel surface and that enough pressure was present to eliminate the excess of composite resin. Lateral excesses were removed using a microbrush and the set was photocured for a total of $50 \mathrm{~s}, 10 \mathrm{~s}$ on each lateral side $\left(0^{\circ}, 90^{\circ}\right.$, $180^{\circ}$ and $270^{\circ}$ ) and $10 \mathrm{~s}$ on the upper face (buccal) of the bracket.

\section{Thermocycling}

Half of the specimens of each group $(n=10)$ was kept in distilled water in a stove (Olidef, Ribeirão Preto, SP, Brazil) at $37^{\circ} \mathrm{C}$ for $24 \mathrm{~h}$, before shear bond testing. The other half was submitted to thermocycling $(n=10)$, in a thermocycler (Nova Ética, São Paulo, SP, Brazil), with a total of 5000 cycles, with temperature ranging from $(5 \pm 1){ }^{\circ} \mathrm{C}$ to $(55 \pm 1){ }^{\circ} \mathrm{C}$, with 30 $\mathrm{s}$ of immersion in each bath and 15 seconds of water drainage, forming a thermal cycle.

\section{Shear bond strength test}

After either being kept in water at $37^{\circ} \mathrm{C}$ for $24 \mathrm{~h}$ or being thermocycled, all specimens were submitted to shear bond testing in a universal testing machine (EMIC DL-1000, EMIC, São José dos Pinhais, PR, Brazil), with a 50 kgf 
load cell. A $0.45 \mathrm{~mm}$ wire was used for the test, being placed on the enamel-adhesive interface (Figure 1), in incise-gingival direction, at $1 \mathrm{~mm}$ / min crosshead speed. SBS is the maximum load needed for debonding or initial failure (either on the adhesive system or on the tooth structure), being recorded in Newton $(\mathrm{N})$, and then converted into megapascal $\left(\mathrm{MPa}=\mathrm{N} \cdot \mathrm{mm}^{-2}\right)$ according to the following ratio: $\mathrm{SBS}=\mathrm{N} / \mathrm{A}$, in which SBS is the shear bond strength (MPa), N is the debonding load required (Newton) and $\mathrm{A}$ is the bonding area developed on the bracket $\left(9.75 \mathrm{~mm}^{2}\right.$ - according to the manufacturer's instructions).

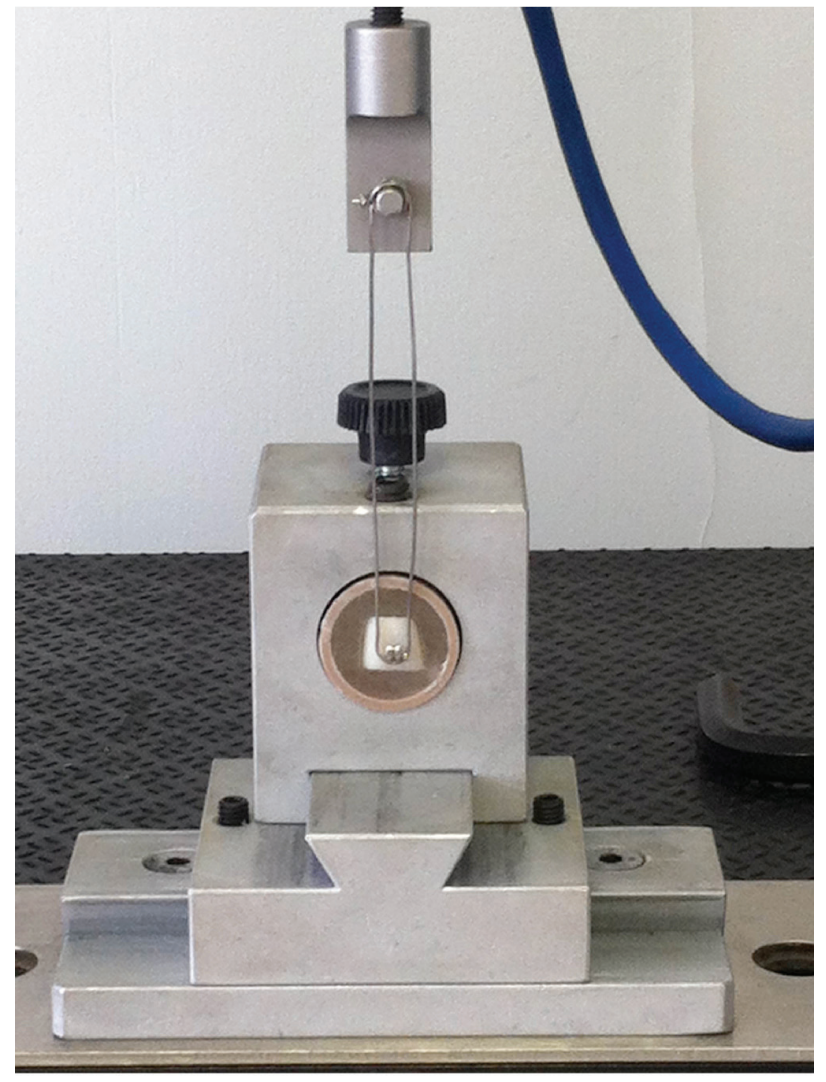

Figure 1- Sample held in position for the SBS test.

\section{Analysis of the failure mode}

After shear bond testing, enamel surface was analyzed under optical stereomicroscope (Discovery V20, Zeiss, Göttingen, Germany) with $10 \times$ magnification to identify the failure mode. Failures were classified according to the composite resin - enamel interface or the enamelorthodontic bracket interface, as following: completely adhesive, between composite resin and enamel; predominantly adhesive, between composite resin and orthodontic bracket; and completely adhesive, between composite resin and orthodontic bracket.

\section{Statistical analysis}

The data were analyzed with the statistical software program MINITAB 17.0 (Minitab, PA, USA). First, the data of descriptive statistics, including mean value and standard deviation, were calculated for all groups. A two-way analysis of variance (ANOVA) test was used for multiple comparisons of SBS between groups and the post hoc Tukey's test were conducted ( $\alpha=0.05)$.

\section{RESULTS}

Descriptive statistical analysis (mean and standard deviation) of SBS (MPa) results for all groups are showed in Table II and Figure 2. Two-way ANOVA (Table II) showed a significant interaction effect for the "adhesive system" factor, which indicated that there was alteration in the SBS according to the type of adhesive ( $\mathrm{p}$ $=0.022$ ). For the factor "thermocycling" there was not significant interaction ( $\mathrm{p}=0.168)$, as well as in the interaction adhesive system + thermocycling concomitantly.

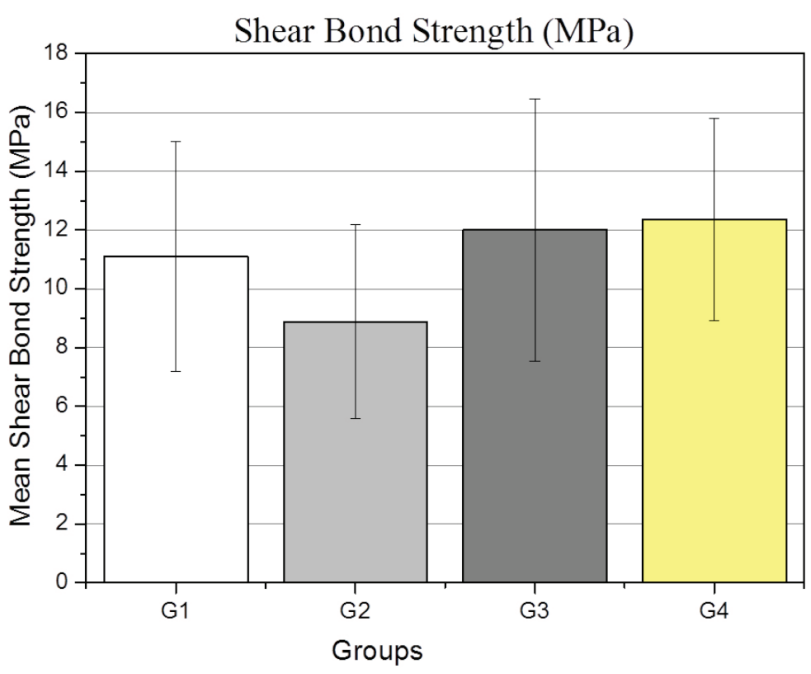

Figure 2 - Mean shear bond strength for the different groups. 
Post-hoc Tukey test showed differences between groups ( $p=0.345$ ) (Table II). For the groups comparing adhesives, without considering thermocycling, G3 presented the highest SBS values $(12.01 \pm 4.46 \mathrm{MPa})$, being statistically similar to the group without adhesive (G1), which presented lower SBS values (11.09 $\pm 3.91 \mathrm{MPa})$. When the interaction between "adhesive system" and "thermocycling" factors are compared, groups G1 and G4 showed statistically different values. G4 presented higher SBS values $(12.36 \pm 3.43 \mathrm{MPa})$ when compared to the other groups.

Table II - Descriptive statistics of shear bond strength (SBS) among experimental groups (MPa)

\begin{tabular}{cccc|}
\hline \multicolumn{3}{c}{ Shear Bond Strength (SBS) } \\
\hline & \multicolumn{3}{c}{ Range } \\
\hline Groups & Mean and SD (MPa) & $\begin{array}{c}\text { Lower limit } \\
(\mathrm{MPa})\end{array}$ & $\begin{array}{c}\text { Upper limit } \\
(\mathrm{MPa})\end{array}$ \\
\hline G1 & $11.09 \pm 3.91^{\mathrm{A}}$ & 5.14 & 20.02 \\
\hline G2 & $8.89 \pm 3.29^{\mathrm{AB}}$ & 5.89 & 13.51 \\
\hline G3 & $12.01 \pm 4.46^{\mathrm{AB}}$ & 7.41 & 21.40 \\
\hline G4 & $12.36 \pm 3.43^{\mathrm{B}}$ & 7.18 & 19.61 \\
\hline
\end{tabular}

${ }^{*}$ Same superscript letters indicate statistical equality.

Results of failure analysis are shown in Table III and in Figure 3. In Figure 3, letter A represents a completely adhesive failure between composite resin and enamel; B represents predominantly adhesive failure, between composite resin and orthodontic bracket and C represents a completely adhesive failure, between composite resin and orthodontic bracket.
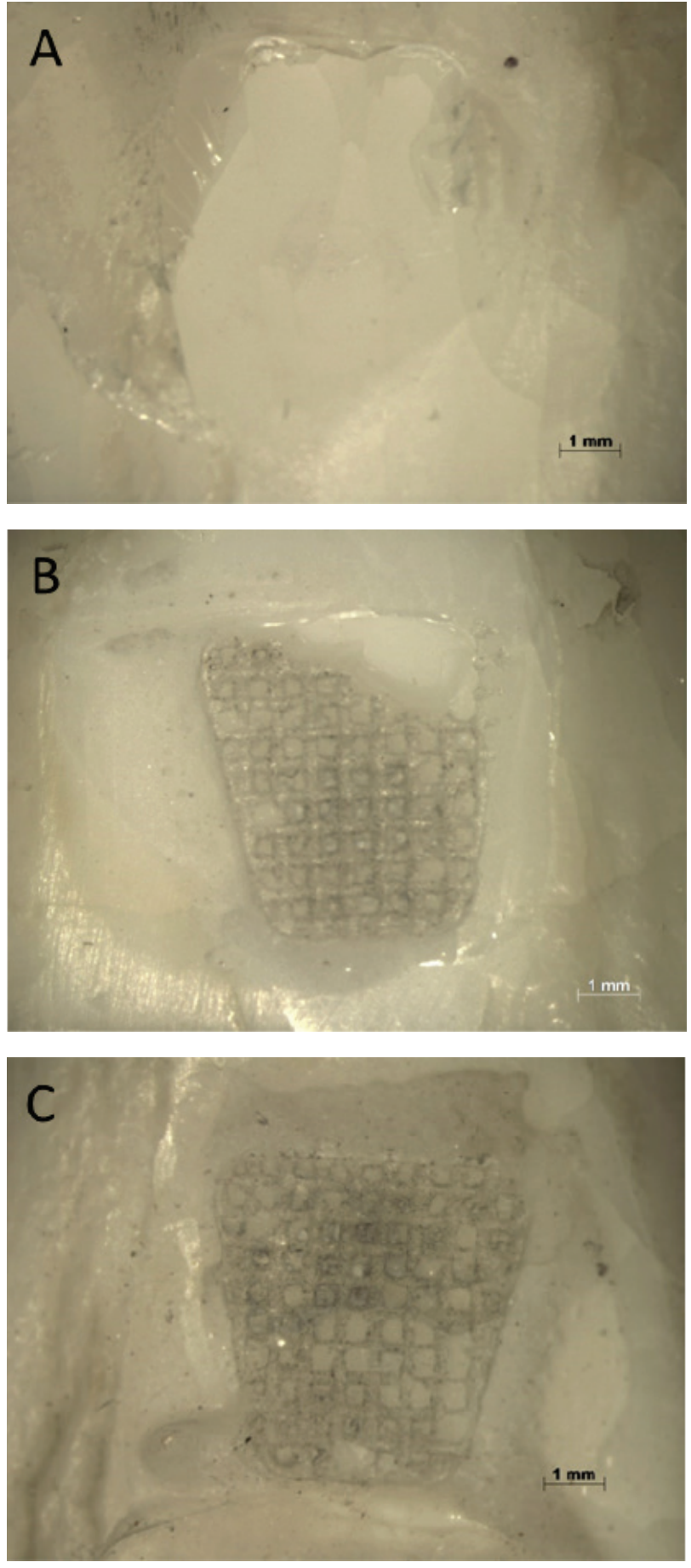

Figure 3 - View of types of failures under stereomicroscope (10x magnification). 
Table III - Frequencies of the failures on the adhesion interface (in \%).

\begin{tabular}{|cccc} 
Groups & $\begin{array}{c}\text { Completely adhe- } \\
\text { sive failure between } \\
\text { composite resin and } \\
\text { enamel }\end{array}$ & $\begin{array}{c}\text { Predominantly } \\
\text { adhesive failure } \\
\text { between com- } \\
\text { posite resinand } \\
\text { orthodontic } \\
\text { bracket }\end{array}$ & $\begin{array}{c}\text { Completely } \\
\text { adhesive fail- } \\
\text { ure between } \\
\text { composite resin } \\
\text { and orthodontic } \\
\text { bracket }\end{array}$ \\
\hline G1 & 1 & 3 & 6 \\
\hline G2 & 7 & 1 & 2 \\
\hline G3 & 3 & 7 & 0 \\
\hline G4 & 3 & 7 & 0 \\
\hline
\end{tabular}

${ }^{*}$ Same superscript letters indicate statistical equality.

Most of the failures in G1 was completely adhesive between composite resin and orthodontic bracket and in G2, completely adhesive between composite resin and enamel. Groups G3 and G4 presented the same frequency of failures. Thermocycling was the factor that diminished SBS between composite resin and enamel only for the group that did not receive the application of adhesive system.

\section{DISCUSSION}

Once the findings of the present study showed that acid etching on enamel surface, on the absence of adhesive, presents clinically acceptable bond strength, but lower in relation to its application, the first null hypothesis was partially accepted. In addition, current findings in the literature highlighted the potential influence of thermocycling/aging [11,12] and the type of adhesive system on bond strength [13], denying the second null hypothesis. Therefore, SBS was affected by both factors: "adhesive system - cementation agent" and "aging - thermocycling".

There is lack of consensus when regarding the usage of adhesive systems in the bonding of orthodontic brackets to enamel $[14,15]$, thus it is indispensable the usage of a material that adequately bonds the bracket to enamel, however not causing any damage to enamel surface. For this matter, in this present study, $35 \%$ phosphoric acid was used, since it is responsible for the dissolution of apatite crystals and the creation of microporosities on the surface morphology [16]. In a previous study, it was demonstrated that for enamel demineralization, the application of 35\% wt and $\mathrm{pH}<1.0$ phosphoric acid is needed [17].

In addition to acid etching of enamel surface, a dry, clean, free of saliva operative field is mandatory, so that the performance of adhesive systems is not affected [18]. It is known that cross-linking methacrylates are the main adhesive-resin component of a bonding system and those are responsible for the bond strength and the integrity of the adhesive layer, although presenting hydrophobic characteristics [19]. The most common are 2,2-bis [4-(3-methacryloyloxy2-hydroxypropoxy)phenyl]propane (Bis-GMA), triethyleneglycol dimethacrylate (TEGDMA) and urethane dimethacrylate (UDMA) [20]. These components are found in the composition of two materials used in this present study, as described by the manufacturers (Table I).

Contact with liquids (such as water) with the composite resin, as well as the thermal shock and the storage period may cause degradation of the resinous matrix [21], which can lead to leaching of these monomers [22]. The main purpose of the adhesion process is based on reliability and durability of the union between substrates, as well as enhance interface chemistry and the capacity of reaction between adhesives and teeth surface. This reaction occurs when the substrate is exposed after the removal of barriers and the adhesive systems applied on the enamel surface are capable of forming direct connections with the substrate [23].

The capacity of shear bond resistance of orthodontic brackets is also dependent on the adhesive system used, even when the bonding agent is absent [24]. It is important to consider that for a successful orthodontic treatment, the maintenance of brackets in the oral cavity for a long period of time is mandatory [25], and this way the aging simulation through thermocycling was proposed. Based on the results of this present study, the higher SBS values were from the group that received bonding of composite resin after the use of the dental adhesive, 
immediately or after aging. However, the results were statistically similar with or without the use of adhesive after thermocycling. This fact shows that it is possible to bond orthodontic brackets effectively, causing less damage to tooth structure [6] and maintaining the effective union between tooth structure and bracket during the orthodontic treatment [26].

Failure analysis can be related to SBS values, since when the bracket was bonded using an orthodontic composite resin after the usage of a bonding system $[3,13,27]$, regardless thermal aging, bond strength was higher, with a higher quantity of predominantly adhesive failures between composite resin and orthodontic bracket (Table II). Unlike the behavior of the groups without adhesive system, the findings of this study showed that thermocycling was an important factor in diminishing SBS values $(8.89 \pm 3.29 \mathrm{MPa})$ and in the presence of a higher quantity of completely adhesive failures between composite resin and enamel, which indicates that the usage of dental adhesive is crucial for maintaining the composite resin on the enamel, enabling a possible reduction of damage chances to tooth structure.

\section{CONCLUSIONS}

- The presence of dental adhesive for the bonding of orthodontic brackets enhances SBS when compared to orthodontic brackets bonded without dental adhesive;

- The presence of dental adhesive contributes to the maintenance of SBS values after thermocycling;

- Enamel surface etching and bonding of orthodontic brackets with composite resin caused less tooth structure damage and presented acceptable bond strength values between orthodontic bracket and tooth structure.

\section{REFERENCES}

1. Buonocore MG. A simple method of increasing the adhesion of acrylic filling materials to enamel surfaces. J Dent Res. 1955 Dec;34(6):849-53.

2. Tavas MA, Watts DC. Bonding of orthodontic brackets by transillumination of a light activated composite: An in vitro study. Br J Orthod. 1979 0ct;6(4):207-8.
3. Sharma S, Tandon P, Nagar A, Singh GP, Singh A, Chugh VK. A comparison of shear bond strength of orthodontic brackets bonded with four different orthodontic adhesives. J Orthod Sci. 2014 Apr;3(2):29-33. doi:10.4103/22780203.132892.

4. Bakhadher W, Halawany H, Talic N, Abraham N, Jacob V. Factors affecting the shear bond strength of orthodontic brackets - a review of in vitro studies. Acta Medica (Hradec Kralove). 2015;58(2):43-8. doi: 10.14712/18059694.2015.92.

5. Tayebi A, Fallahzadeh F,Morsaghian M. Shear bond strength of orthodontic metal brackets to aged composite using three primers. J Clin Exp Dent. 2017 Jun 1;9(6):e749-e755. doi: 10.4317/jced.53731. eCollection 2017 Jun.

6. Chu CH, Ou KL, Dong de R, Huang HM, Tsai HH, Wang WN. Orthodontic bonding with self-etching primer and self-adhesive systems. Eur J Orthod. 2011 Jun;33(3):276-81. doi: 10.1093/ejo/cjq073. Epub 2010 Aug 20.

7. Scougall Vilchis RJ, Yamamoto S, Kitai N, Yamamoto K. Shear bond strength of orthodontic brackets bonded with different self-etching adhesives. Am J Orthod Dentofacial Orthop. 2009 Sep;136(3):425-30. doi:10.1016/j. ajodo.2007.08.024.

8. Büyükyilmaz T,Zachrisson BU. Improved orthodontic bonding to silver amalgam. Part2. Lathe-cut, admixed, and spherical amalgams with different intermediate resins. Angle Orthod. 1998 Aug;68(4):337-44.

9. Bayram M, Yesilyurt C, Kusgöz A, Ulker M, Nur M. Shear bond strength of orthodontic brackets to aged resin composite surfaces: Effect of surface conditioning. Eur J Orthod. 2011 Apr;33(2):174-9. doi: 10.1093/ejo/cjq048. Epub 2010 Jul 21.

10. Finnema KJ, Özcan M, PostWJ, Ren Y,Dijkstra PU. In-vitro orthodontic bond strength testing: A systematic review and meta-analysis. Am J Orthod Dentofacial Orthop. 2010 May;137(5):615-622.e3. doi:10.1016/j.jajodo.2009.12.021.

11. Sokucu 0, Siso SH, OzturkF, Nalcaci R. Shear bond strength of orthodontic brackets cured with different light sources under thermocycling. Eur J Dent. 2010 Jul;:4(3):257-62.

12. De Abreu Neto HF, Costa AR, Correr AB, Vedovello SA, Valdrighi HC, Santos $\mathrm{EC}$, etal. Influence of light source, thermocycling and silane on the shear bond strength of metallic brackets to ceramic. Braz Dent J. 2015 NovDec;26(6):685-8. doi: 10.1590/0103-6440201300416.

13. Zope A,Zope-Khalekar Y, Chitko SS, Kerudi VV, Patil HA, Bonde PV, etal. Comparison of self-etch primers with conventional acid etching system on orthodontic brackets. J Clin Diagn Res. 2016 Dec;10(12):ZC19-ZC22. do: 10.7860/JCDR/2016/18842.9031. Epub 2016 Dec 1.

14. Reicheneder CA, Gedrange T, Lange A, BaumertU,Proff P.Shear and tensile bond strength comparison of various contemporary orthodontic adhesive systems: an in-vitro study. Am J Orthod Dentofacial Orthop. 2009 Apr;135(4):422et-6; discussion 422-3. doi: 10.1016/j.ajodo.2008.12.001.

15. Atash R, Fneiche A, Cetik S, Bahrami B, Balon-Perin A, Orellana M, etal. In vitro evaluation of microleakage under orthodontic brackets bonded with different adhesive systems. Eur J Dent. 2017 Apr-Jun;11(2):180-185. doi:10.4103/ejd. ejd $312 \_16$.

16. Stangel I, Ellis TH, Sacher E. Adhesion to tooth structure mediated by contemporary bonding systems. Dent Clin North Am. 2007 Jul;51(3):677-94, vii.

17. Barkmeier WW, Erickson RL Shear bond strength of composite to enamel and dentin using scotchbond multi-purpose. Am J Dent. 1994 Jun;7(3):175-9.

18. Maia SR, Cavalli V, Liporoni PC, do Rego MA. Influence of saliva contamination on the shear bond strength of orthodontic brackets bonded with self-etching adhesive systems. Am J Orthod Dentofacial Orthop. 2010 Jul;;38(1):79-83. doi: 10.1016/j.jajodo.2008.08.035. 
19. Moszner N, Salz U,Zimmerman J.Chemical aspects of self-etching enameldentin adhesives: a systematic review. Dent Mater. 2005 0ct,21(10):895-910.

20. Imazato S, McCabe JF, Tarumi H, Ehara A, Ebisu S. Degree of conversion of composites measured by DTA and FTIR. Dent Mater. 2001Mar;:17(2):178-83.

21. Geurtsen W. Biocompatibility of resin-modified filling materials. CritRev Oral Biol Med. 2000;1(3):333-55.

22. Tabatabaei MH, Sadrai S, Bassir SH, Veisy N, Dehghan S. Effect of food stimulated liquids and thermocycling on the monomer elution from a nanofilled composite. Open Dent J.2013 Jul 26;7:62-7. doi: 10.2174/1874210601307010062. eCollection 2013.

23. Stangell,Ellis TH, Sacher E. Adhesion to tooth structure mediated by contemporary bonding systems. Dent Clin North Am. 2007 Jul;51(3):677-94, vii.
24. Shahabi M, Heravi F, Mokhber N, Karamad R, Bishara SE. Effects on shear bond strength and the enamel surface with an enamel bonding agent. Am J Orthod Dentofacial Orthop. 2010 Mar;137(3):375-8. doi:10.1016/j.ajodo.2008.03.030.

25. Khosravanifard B, Nemati-Anaraki S, Faraghat S, Sajjadi SH, Rakhshan H, Rakhshan V. Efficacy of 4 surface treatments in increasing the shear bond strength of orthodontic brackets bonded to saliva-contaminated direct composites. Orthod Waves. 2011;70:65-70.

26. Cumerlato M, Lima EM, Osorio LB, MotaEG, Menezes LM, Rizzatto SMD. Effect of surface treatment of prefabricated teeth on shear bond strength of orthodontic brackets. Dental Press J Orthod. 2017 Jul-Aug;22(4):47-52. doi: 10.1590/2177-6709.22.4.047-052.oar.

27. Scribante A, Sfondrini MF,Fraticelli D, Daina P, Tamagnone A, Gandini P. The influence of no-primer adhesives and anchor pylons bracket bases on shear bond strength of orthodontic brackets. Biomed Res Int. 2013;2013:315023. doi: 10.1155/2013/315023. Epub2013 Aug 4.

\section{Jaiane Bandoli Monteiro}

(Corresponding address)

Institute of Science and Technology, Paulista State University

(UNESP), Department of Dental Materials and Prosthodontics.

777 Eng. Francisco José Longo Avenue, Jardim São Dimas,

São José dos Campos, São Paulo.

CEP: 12245000 .

e-mail: jaiane.monteiro@ict.unesp.br

Date submitted: 2018 May 20

Accept submission: 2018 Aug 23 